\title{
Potensi Air Tanah Di Daerah Rapporappowa dan Kalukuang, Desa Rewataya Pulau Tanakeke, Kecamatan Mappakasunggu Kabupaten Takalar, Provinsi Sulawesi Selatan
}

\author{
Sultan \\ Departemen Teknik Geologi, Fakultas Teknik UNHAS \\ sultanhamyahya@gmail.com
}

\begin{abstract}
Abstrak
Observasi air tanah di daerah ini bertujuan untuk mengetahui potensi air yang terkandung pada lapisan tanah dan batuan di daerah ini berdasarkan hasil interpretasi geolistrik resistivity yang dikorelasikan dengan kondisi geologi daerah ini, menghasilkan jenis lapisan, ketebalan dan kedalaman lapisan tanah dan batuan berdasarkan nilai resistivitas serta menentukan potensi air tanah yang terkandung di Daerah Rapporappowa dan Daerah Kalkukuang, Desa Rewataya, Pulau Tanakeke, Kecamatan Mappakasunggu, Kabupaten Takalar, Provinsi Sulawesi Selatan. Metode pengamatan yang digunakan adalah langsung di lapangan melakukan pengamatan kondisi geologi lokal di daerah Pulau Tanakeke, melakukan pengukuran geolistrik resisitivty dan membuat interpretasi berupa penampang resistivity serta hasil analisis potensi air tanah di daerah pulau tersebut dan merekomendasikan model pengelolaan air tanah di daerah Pulau ini.

Hasil pemetaan geologi, pengukuran dan analisis geolistrik resisitivity yang menghasilkan penampang resisitivity maka dibuat kesimpulan susunan lapisan tanah dan batuan secara vertikal di Daerah Rapporappowa dan Kalukuang, Desa Rewataya, Pulau Tanakeke, secara umum terdiri dari lapisan tanah penutup (0-1,5 m), pasir terumbu (1,5-4,5 $\mathrm{m})$, batugamping terumbu $(4,5-15 \mathrm{~m})$ batugamping berongga $(15-40 \mathrm{~m})$, batugamping retak $(40-52 \mathrm{~m})$, batugamping agak keras $(52-60 \mathrm{~m})$, batugamping keras $(60-73 \mathrm{~m})$ dan batugamping sangat keras $(73-103 \mathrm{~m})$. Lapisan pasir terumbu di daerah ini mengandung air asin begitu juga dengan lapisan batugamping terumbu sampai batugamping keras dari permukaan sampai kedalaman terdeteksi sekitar 103 meter mengandung air asin dan tidak mempunyai potensi kandungan air tanah yang bersifat tawar.

Model pengelolaan sumber daya air tanah di Daerah Rapporappowa dan Kalukuang, Desa Rewataya, Pulau Tanakeke, Kecamatan Mappakasunggu, Kabupaten Takalar ini hanya bisa dilakukan dengan Sistem Desalinasi dan penyulingan air laut menjadi air tawar dengan tingkat kejernihan yang baik sehingga bisa dimanfaatkan oleh warga di daerah pulau ini.
\end{abstract}

Kata Kunci: Potensi Air Tanah; Resistivitas; Lapisan Batuan; Model Pengelolaan.

\section{Pendahuluan}

\subsection{Latar Belakang}

Batuan penyusun dari pulau-pulau kecil bervariasi, secara genesa salah satunya yang dominan adalah batuan terumbu (batugamping/batukapur). Di Indonesia, genesa batuan pulau-pulau kecil secara umum dikelompokkan sebagai pulau vulkanik, pulau tektonik, pulau relik paparan, pulau delta dan pulau terumbu. Pengelompokan genesa ini menghasilkan gambaran morfologi, tipe atau jenis tanah/batuan, nilai tanahan jenis (resistivitas), nilai konduktivitas serta zona dispersi air tanah yang berbeda antara satu pulau dengan pulau lainnya, tergantung kondisi geologi (jenis tanah dan batuan) dan kondisi geohidrologi pada daerah pulau-pulau kecil tersebut (Adang, 2009).

Pulau dengan morfologi berbukit dan berpantai curam umumnya mempunyai jenis tanah/batuan yang mencirikan pulau tektonik dan pulau vulkanik atau pulau relik paparan, sementara 
morfologi pulau yang relatif landai dan datar umumnya kondisi tipe tanah/batuan mencirikan bentuk pulau delta atau pulau terumbu (Hantoro, 2009).

Pada pulau-pulau kecil sering dijumpai masalah kekurangan air, karena jumlah air tanah yang tawar jauh lebih sedikit dibandingkan dari pulau-pulau besar dan juga karena berat jenis air tawar lebih kecil dari berat jenis air laut sehingga mudah terintrusi. Disamping itu, pengambilan air dapat berlangsung cepat terutama bila dilakukan dengan pemompaan, tetapi pengembalian air tanah membutuhkan waktu yang sangat panjang karena secara alami harus melalui pori tanah yang kecil. Karena itu, pulau-pulau kecil perlu dilakukan pelestarian air tanah tawar yang intensif (Siti Fatimah, 2006).

Jenis tanah/batuan yang menyusun pulau kecil biasanya berbeda dan bervariasi, misalnya tersusun oleh jenis tanah/batuan terumbu (batu gamping), dari batuan vulkanik atau batuan aktivitas tektonik maupun yang bersumber dari delta (alluvial) akan memberikan lapisan potensi air yang berbeda-beda (Arenas, 1991).

Jenis tanah/batuan yang bervariasi akan memberikan nilai resistivitas yang berbeda (Eva Rolia, 2011). Sebaran 2 dimensi keterdapatan air tanah berdasarkan nilai resistivitas tanah dan batuan serta mempertimbangkan aspek geologi dan hidrogeologi daerah pulau kecil tersebut, maka potensi air tanah yang terkandung pada lapisan batuan di Daerah Pulau Tanakeke, Desa Rewataya, Kabupaten Takalar dapat diketahui sebagai salah satu acuan dalam menentukan model pengelolaan sumber daya air di daerah pulau tersebut.

Tujuan pelaksanaan pengamatan di Daerah Rapporappowa dan Kalukuang, Desa Rewataya Pulau Tanakeke, Kabupaten Takalar ini adalah:

a. Analisis lapisan tanah dan lapisan batuan berdasarkan kondisi geologi regional serta interpretasi geolistrik di Daerah Rapporappowa dan Kalukuang.

b. Analisis ketebalan dan kedalaman lapisan pasir terumbu berdasarkan nilai resistivitas

c. Analisis potensi air tanah yang terkandung pada lapisan batuan di daerah ini.

d. Model pengelolaan sumber daya air tanah di daerah pulau ini.

e. Dengan terlaksananya pengamatan potensi air tanah di daerah ini, maka diharapkan manfaat yang didapat secara umum dan khusus yang bias diterapkan di daerah ini adalah:

f. Mengetahui ketebalan, kedalaman dan sebaran secara horisontal lapisan tanah dan batuan berdasarkan kondisi geologi dan nilai resistivitas hasil pengukuran geolistrik untuk analisis potensi air tanah di Daerah Rapporappowa dan Kalukuang, Desa Rewataya, Pulau Tanahkeke, Kecamatn Mappakasunggu, Kabupaten Takalar.

g. Model pengelolaan sumber daya air yang terdapat di daerah ini yang sesuai dengan potensi dan keberadaan air tanah di daerah ini.

\subsection{Lokasi dan Waktu Pengamatan}

Pengamatan dilaksanakan di Pulau Tanakeka pada lokasi Daerah Rapporappowa dan Kalukkuang, Desa Rewataya, Kecamatan Mappakasunggu, Kabupaten Takalar, Provinsi Sulawesi Selatan (Gambar 1). Perhitungan dan pengolahan data serta analisis dan interpretasi dilaksanakan di Laboratorium Geofisika, Departemen Teknik Geologi, Fakultas Teknik Universitas Hasanuddin. Pengambilan data lapangan dilakukan pada tanggal 10 - 12 Februari 2017 yang selanjutnya diolah, dianalisis dan interpretasi. 


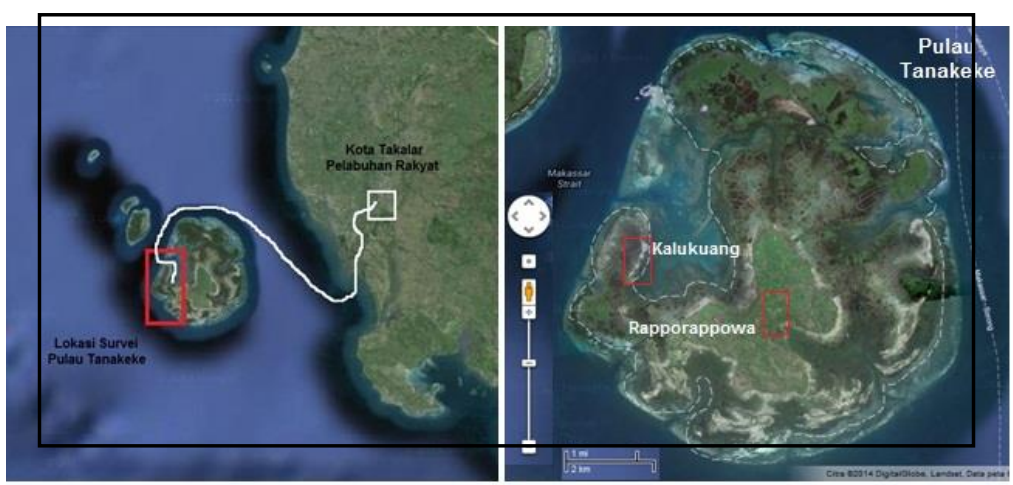

Gambar 1. Lokasi Pengukuran Geolistrik Resistivity di Daerah Rapporapowa dan Kalukuang, Pulau Tanakeke, Desa Rewataya, Kabupaten Takalar.

\section{Metode Pengamatan}

Metode pengamatan yang dilakukan secara umum dibagi 3 bagian, sebagai berikut:

a. Pemetaan geologi dilakukan dengan melaksanakan kegiatan:

1. Pengamatan kondisi geologi permukaan dan jenis batuan yang bisa bertindak sebagai lapisan potensi air tanah dan memprediksi kualitas kandungan airnya.

2. Memberikan masukan susunan lapisan tanah secara vertikal yang nantinya akan dinasabahkan dengan data pemodelan geolistrik resistivity.

b. Pengukuran geolistrik resistivity, kegiatan meliputi:

1. Pelaksanaan pengukuran geolistrik resistivity di lokasi titik yang representatif.

2. Melakukan pengolahan data dan membuat interpretasi berdasarkan model penampang resistivity berdasarkan Software Res2dinv dan data geologi.

3. Mengidentifikasi lapisan batuan yang bertindak sebagai lapisan potensi air tanah (lapisan akuifer) berdasarkan sebaran nilai resistivity yang mewakili setiap lapisan.

4. Memberikan masukan susunan, ketebalan, kedalaman lapisan tanah/ batuan secara vertikal untuk menunjang pembuatan model potensi air tanah di pulau tersebut.

c. Kegiatan Interpretasi dan rekomendasi model pengelolaan air tanah, meliputi:

1. Mengetahui susunan lapisan, ketebalan dan kedalaman serta potensi air tanah berdasarkan hasil penampang geolistrik resistivity di Pulau Tanakeke.

2. Model pengelolaan air tanah di Daerah Pulau Tanakeke, Desa Rewataya, Kecamatan Mappakasunggu, Kabupaten Takalar, Provinsi Sulawesi Selatan.

\subsection{Peralatan dan Bahan}

Peralatan dan bahan yang digunakan dalam pelaksanaan pengamatan (Gambar 2) adalah: 


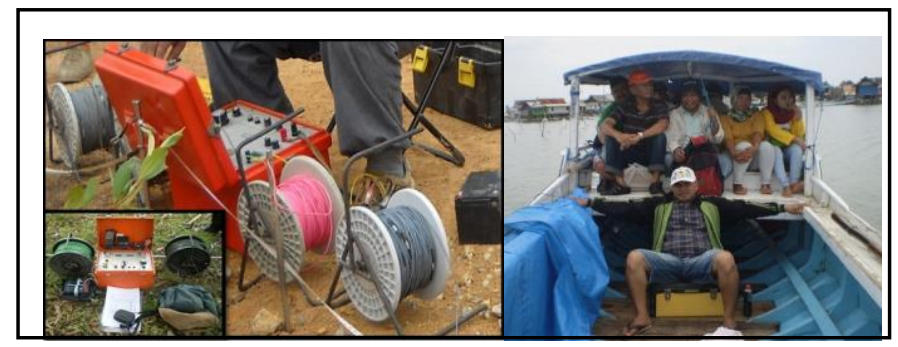

Gambar 2. Peralatan Geolistrik Resistivity (Naniura NRD 300 HF) dan Transportasi Laut ke Lokasi Pulau Tanakeke, Desa Rewataya, Kabupaten Takalar.

a. Peta Geologi Lembar Ujungpandang, Benteng dan Sinjait, Sulawesi skala 1 : 250.000 .

b. Peta Topografi Bakosurtanal (Lembar Takalar, Skala 1 : 50.000 tahun 1991)

c. Palu Geologi, Kompas Geologi dan GPS MAP Tipe Garmin 76 CSx

d. Buku catatan lapangan, Kamera Digital dan Komputer/Laptop

e. 2 buah Rollmeter (100 meter ) dan Tabel Data dan Alat tulis menulis

f. Radio Komunikasi (Handy Talking) 3 buah dan 4 buah Palu untuk elektroda

g. Alat Geolistrik (Resistivimeter Naniura NRD 300 HF)

h. Roll kabel ukuran 500 meter 2 buah dan Roll Kabel ukuran 100 meter 2 buah

i. 2 buah Elektroda Potensial dan 2 buah Elektroda Arus

\subsection{Jenis Tanah Dan Batuan}

Kabupaten Takalar, khususnya Kecamatan Mappakasunggu merupakan salah satu wilayah Kecamatan di Provinsi Sulawesi Selatan yang memiliki daerah pulau yang terdiri dari pulau kecil dengan genesa tanah/batuan yang berbeda, namun berdasarkan kondisi geologi regional (Sukamto dan Supriatna, 1982), selain mempunyai wilayah daratan yang tersusun oleh tanah dan batuan yang bervariasi daerah ini juga mempunyai wilayah pulau kecil yang tersusun oleh tanah dan batuan dari terumbu (batu gamping).

Jenis tanah/batuan yang beda akan menunjukkan bentuk zona dispersi air tanah yang berbeda dan akan berpengaruhi ke bentuk akifer yang terdapat di pulau. Pulau yang jenis tanah/batuannya tersusun oleh terumbu akan beda dengan pulau yang tersusun oleh tanah/batuan dari vulkanik, delta, beku, metamorf (Muhammad Irfan, 2009).

Potensi dan ketersediaan air tanah, khususnya di pulau kecil sangat tergantung pada kondisi dispersi air tanah pada daerah tersebut yang dipengaruhi oleh jenis tanah/batuan, kondisi geologi, geohidrologi dan meteorologi (Agus Laesanpura, 2009).

\subsection{Kondisi Topografi}

Kondisi topografi setiap pulau bervariasi tergantung genesa tanah/batuan pada pulau tersebut, dimana kondisi topografi dapat mencirikan jenis tanah/batuan yang menyusunnya. Ada pulau yang tersusun oleh tanah/batuan vulkanik, ada yang terbentuk akibat aktivitas tektonik serta ada juga yang terbentuk akibat relik paparan serta akumulasi delta maupun dari terumbu atau batugamping (Noorhadi, 2008).

Pulau dengan topografi berbukit dan berpantai curam umumnya mencirikan tanah/ batuannya tersusun oleh batuan akibat aktivitas tektonik, vulkanik atau relik paparan, sementara topografi pulau yang landai dan datar umumnya kondisi tanah/batuannya mencirikan terbentuk dari batuan delta atau batuan terumbu karang (Jamal, 2012). 


\subsection{Metode Geolistrik Tahanan Jenis (Resistivity)}

Metoda Geolistrik Tahanan Jenis merupakan salah satu metoda geofisika yang dapat memberikan gambaran susunan dan kedalaman lapisan batuan, dengan mengukur sifat kelistrikan batuan. Geolistrik metoda resistivitas mapping / sounding menghasilkan informasi perubahan variasi harga resistivitas baik arah lateral maupun arah vertikal di suatu daerah. Setiap batuan yang berbeda akan mempunyai harga resistivitas yang berbeda, ini tergantung pada faktor, umur batuan, kandungan elektrolit, kepadatan, jumlah mineral yang dikandungnya, porositas dan permeabilitas (Cindhy, dkk., 2012).

Selain pengukuran geolistrik seperti Gambar 1, dilakukan pemetaan geologi permukaan dengan mengamati jenis tanah/batuan, dan sampel batuan untuk analisis laboratorium.

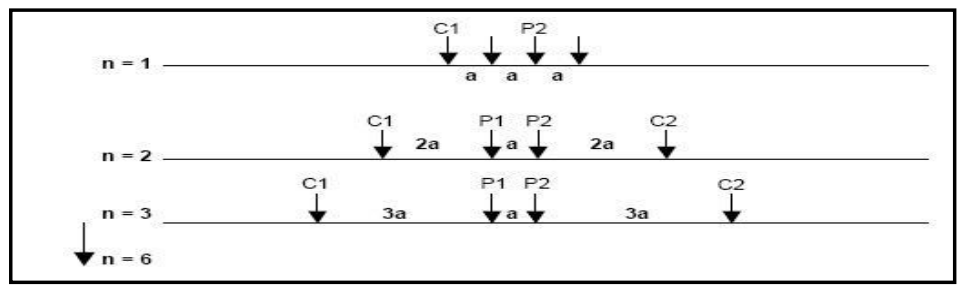

Gambar 3. Pengukuran Geolistrik dengan Konfigurasi Schlumberger ( Sumber: Telford 1990)

\subsection{Nilai - Nilai Resistivitas Tanah Dan Batuan}

Pengukuran geolistrik dengan metode sounding menggunakan susunan elektroda metode schlumberger, pengukuran metode mapping menggunakan susunan elektroda memakai gabungan wenner-schlumberger potensial MN dan arus AB (Sultan, 2008).

Pengukuran geolistrik resistivitas metode sounding dan susunan elektroda schlumberger harus memenuhi syarat jarak MN/2 jangan melebih jarak maksimal 1/5 dari AB/2. Bentangan elektroda arus selalu berubah setiap pengukuran, maka harga tahanan jenis semu diperoleh dari rumus (Dwiyanto 2009; Akos, 2010) sebagai berikut:

$$
\begin{aligned}
& \Omega=K \cdot \frac{V}{I} \ldots \ldots \ldots \\
& K=\frac{\pi}{4 a} \cdot\left(\mathrm{L}^{2}-a^{2}\right)
\end{aligned}
$$

dimana:

$$
\begin{array}{ll}
\Omega=\text { tahanan jenis semu (Ohm-meter) } & \mathrm{V}=\text { beda potensial }(\mathrm{mVolt}) \\
\mathrm{I}=\text { beda arus yang digunakan (m Ampere) } & \pi=\text { nilai phi koreksi } 3,14 \\
\mathrm{a}=\text { jarak bentangan MN (meter) } & \mathrm{K}=\text { koefisien geometris } \\
\mathrm{L}=\text { jarak bentangan } \mathrm{AB} \text { (meter) } &
\end{array}
$$


Tabel 1. Nilai resistivitas jenis tanah dan batuan (Sumber: Vingoe,1972 dalam Telford,1990)

\begin{tabular}{llll}
\hline Jenis Tanah & Resistivitas (Ohm.m) & Jenis Batuan & Resistivitas (Ohm.m) \\
\hline lempung/napal & $1-10^{3}$ & Pasir/kerikil & $10-10^{4}$ \\
tanah liat & $10-10^{2}$ & Kapur & $10-10^{3}$ \\
tanah lempung & $10^{2}-10^{4}$ & Batugamping & $10^{2}-10^{5}$ \\
tanah pasiran & $10^{2}-10^{3}$ & Batupasir & $10^{2}-10^{6}$ \\
tanah lepas & $10^{2}-10^{5}$ & batuan kristalin & $10^{3}-10^{7}$ \\
\hline
\end{tabular}

Nilai resitivitas masing-masing jenis tanah/batuan dapat dibedakan seperti yang ditampilkan oleh Vingoe (1972) dalam (Telford., et al., 1990) seperti pada tabel 1. Memodelkan lapisan tanah dan batuan yang terdapat di pulau kecil dapat dilakukan dengan membuat penampang 2D resistivitas berdasarkan nilai resistivitas (tahanan jenis) menggunakan software Res2dinv Versi 3.54p (Zbigniew, 2011).

Landasan teori mengacu pada keterkaitan bidang keilmuan, dalam hal ini ilmu keteknikan yang digunakan dalam menjawab permasalahan yang diangkat dalam bagian awal dari Bab Pendahuluan. Bagian teori ini dapat berupa artikel-artikle ilmiah, artikel dalam jurnal, buku atau sumber lain yang bersifat ilmiah. Dalam konteks pengabdian masyarakat, teori mendasar yang digunakan adalah teori-teori yang mengacu pada aplikasi kemasyarakatan, pengembangan komunitas atau pelayanan masyarakat. Teori lainnya yang masih perlu dikembangkan untuk menyelesaikan permasalahan yang dapat dipaparkan setelahnya.

Setelah lendasan teori dikemukakan, penulis menyatakan hipotesa sementara (jika ada) sebagai rujukan dalam menjawab permasalahan yang diangkat. Jika hipotesa tersebut bernilai kebenaran makan penulis dapat menyatakan bahwa pendekatan yang digunakan dapat memberikan solusi.

\section{Potensi Air Tanah Di Daerah Rapporappowa dan Kalukuang}

\subsection{Kondisi Geologi Daerah Rapporappowa dan Kalukuang, Pulau Tanakeke}

Berdasarkan relief, topografi dan batuan penyusun daerah pengamatan dapat dibagi atas satuan geomorfologi pedataran aluvial pantai. Satuan geomorfologi pedataran alluvial pantai menyusun Daerah Rapporappowa dan Kalukuang, Pulau Tanakeke ini yang relatif memanjang utara selatan. Elevasi daerah ini berkisar antara 0,5-1,5 meter di atas permukaan laut, dengan kondisi daerah yang datar dan sebagian tertutupi oleh vegetasi pohon bakau serta rumah pemukiman warga pulau sekitar 228 rumah. Morfologi pedataran ini dibentuk oleh endapan hasil kegiatan aktivitas pantai, dengan konsolidasi pada bagian permukaan hampir tidak ada dan sedimentasi yang terjadi tingkat sedang, dengan dijumpainya hasil aktivitas sedimentasi pantai di seluruh daerah pulau.

Berdasarkan litologinya, batuan penyusun terdiri dari 4 lapisan batuan : Batugamping dari Formasi Tonasa, Batugamping terumbu, pasir terumbu dan endapan alluvial pantai. Satuan Batugamping Formasi Tonasa (Temt) yang menyusun bagian bawah Formasi batuan di Pulau Tanakeke dan sekitarnya ini berumur dari Eosen Akhir-Miosen Tengah dan menindih tak selaras batuan yang lebih tua dibawahnya. Berdasarkan sebaran daerah singkapannya, batugamping yang dipetakan sebagai batuan karbonat yang menyusun bagian bawah daerah ini dan pulaupulau sekitarnya menghasilkan endapan karbonat yang tebalnya 1750 meter. Data singkapan 
yang didapat di pulau ini terlihat bahwa kenampakan batugamping yang ada berwarna segar abuabu kekuningan sampai kelabu kecoklatan dengan warna lapuk dari abu-abu kehitaman dan di beberapa tempat dijumpai adanya fragmen cangkang dan terumbu yang berada di dalam batugamping. Lapisan batugamping ini sampai kedalaman yang terdeteksi dan terekam oleh geolistrik resistivity (103 meter) masih menunjukkan lapisannya mengandung air asin.

Lapisan batugamping terumbu yang berumur Holosen di daerah pulau ini berada di atas satuan batugamping dari Formasi Tonasa. Batugamping terumbu ini tersingkap berada di bawah lapisan pasir terumbu dengan ketebalan sekitar 10 meter berdasarkan hasil interpretasi geolistrik resistivity. Batuan ini mengandung air laut yang bersifat asin.

Lapisan pasir terumbu yang berumur Holosen di daerah pulau ini berada di atas satuan batugamping terumbu. Pasir terumbu ini tersingkap berada di bawah lapisan endapan aluvial pantai dengan ketebalan sekitar 5 meter berdasarkan hasil interpretasi geolistrik resistivity dan lapisan pasir terumbu ini mengandung air laut yang bersifat asin.

Endapan alluvial yang menyusun daerah Pulau Tanakeke ini berupa endapan alluvial pantai yang berasal dari aktivitas pantai di pulau tersebut. Material penyusun endapan alluvial ini berukuran dari lanau sampai pasir kasar yang tidak terkonsolidasi dan secara tidak selaras berada di atas lapisan pasir terumbu di daerah pulau ini.

Material endapan alluvial pantai daerah pulau ini sebagian besar bersifat karbonat dan hancuran terumbu karang. Ketebalan lapisan endapan aluvial ini bervariasi dari sekitar 0,5 - 1,5 meter dengan kondisi ketebalan lapisan aluvial dari garis pantai ke arah bagian tengah pulau yang semakin menebal, namun mengandung air asin.

Hasil interpretasi geolistrik yang dinasabahkan dengan data geologi menunjukkan bahwa secara keseluruhan sampai kedalaman sekitar 103 meter lapisan tanah dan batuan di Pulau Tanakeke ini semuanya mengandung air asin.

\subsection{Pengukuran Geolistrik Resistivity}

Pengukuran geolistrik di lokasi daerah ini menggunakan peralatan geolistrik resistivity Naniura tipe NRD $300 \mathrm{HF}$ dengan lokasi titik duga sebagai berikut :

a. Titik Geolistrik GL.01 di wilayah Daerah Rapporappowa, Desa Rewataya, Kabupaten Takalar dengan koordinat: $05^{\circ} 29^{\prime} 52,5^{\prime}$ S $119^{\circ} 15^{\prime} 22,0^{\prime \prime} \mathrm{E}$, bentangan kabel elektroda 400 meter $(2 \times 200 \mathrm{~m})$ yang berarah relatif Timur Laut - Barat Daya $\left(\mathrm{N} 220^{\circ} \mathrm{E}\right)$, mendeteksi kedalaman secara vertikal hingga kedalaman 103 meter. Nilai resisitivity hasil pengukuran geolistrik adalah antara $0,17-17,9 \Omega$ meter.

b. Titik Geolistrik GL.02 di wilayah Daerah Kalukuang, Desa Rewataya, Kabupaten Takalar dengan koordinat: $05^{\circ} 29^{\prime} 38,4^{\prime}$ ' S $119^{\circ} 15^{\prime} 30,1^{\prime \prime}$ E, bentangan kabel elektroda 400 meter (2 x $200 \mathrm{~m}$ ) yang berarah relatif Timurlaut-Baratdaya $\left(\mathrm{N} 210^{\circ} \mathrm{E}\right)$, mendeteksi kedalaman secara vertikal hingga kedalaman 103 meter. Nilai resisitivity hasil pengukuran geolistrik adalah antara $0,15-20,3 \Omega$ meter. 


\subsection{Analisis Geolistrik Resistivity dengan Penampang}

Hasil pengukuran geolistrik resistivity di titik GL.01 di Daerah Rapporappowa, Desa Rewataya, Pulau Tanakeke ini diperoleh susunan lapisan tanah dan batuan secara vertikal ke bawah permukaan yang ditunjukkan oleh perbedaan nilai resistivity dan beda warna lapisan sebanyak 8 lapisan berdasarkan penampang seperti Gambar 4.

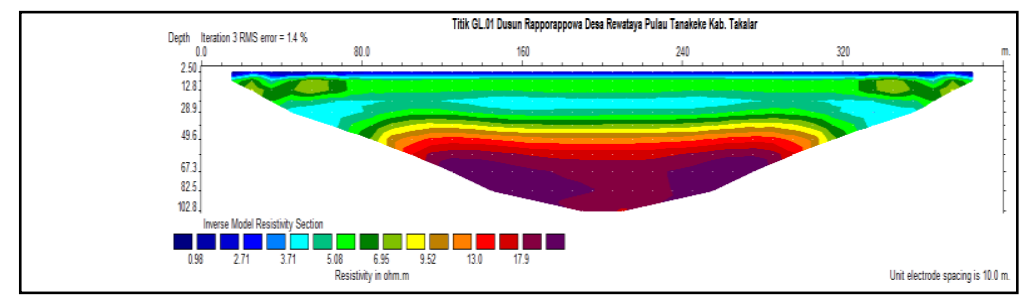

Gambar 4. Penampang Resistivity Geolistrik Lapisan Tanah/Batuan Pengukuran Geolistrik di GL.01 Pulau Tanakeke dengan Interpretasi Kedalaman sekitar 103 Meter.

Susunan lapisan batuan yang terekam dan diinterpretasikan lapisannya sebagai berikut:

a. Lapisan pertama dengan nilai resistivitas $0,17-2 \Omega \mathrm{m}$ dan kedalaman $0-1,5$ meter merupakan lapisan tanah penutup yang berupa alluvial pantai, mengandung air asin.

b. Lapisan kedua, nilai resistivitas $2-3 \Omega$ m dan kedalaman 1,5-4,5 meter merupakan lapisan pasir terumbu yang mengandung air asin dan material berukuran pasir.

c. Lapisan ketiga, nilai resistivitas $3-4 \Omega$ m dan kedalaman 4,5 - 15 meter merupakan lapisan batugamping terumbu yang mengandung material cangkang dan air asin.

d. Lapisan keempat, nilai resistivitas $4-6 \Omega \mathrm{m}$ dan kedalaman $15-40$ meter merupakan lapisan batugamping berongga yang mengandung air asin.

e. Lapisan kelima, nilai resistivitas 6-9 $\Omega \mathrm{m}$ dan kedalaman 40 - 52 meter merupakan lapisan batugamping retak yang agak lunak dan mengandung air asin.

f. Lapisan keenam, nilai resistivitas $9-13 \Omega$ m dan kedalaman $52-60$ meter merupakan lapisan batugamping agak keras yang masih mengandung air asin.

g. Lapisan ketujuh, nilai resistivitas 13-18 $\Omega \mathrm{m}$ dan kedalaman $60-73$ meter merupakan lapisan batugamping keras yang mengandung air asin.

h. Lapisan kedelapan, nilai resistivitas > $18 \Omega \mathrm{m}$ dan kedalaman 73-103 meter merupakan lapisan batugamping yang sangat keras dan masih mengandung air asin.

Hasil pengukuran geolistrik resistivity di titik GL.02 di Daerah Dusun Kalukuang, Desa Rewataya, Pulau Tanakeke ini diperoleh susunan lapisan tanah dan batuan secara vertikal ke bawah permukaan yang ditunjukkan oleh perbedaan nilai resistivity dan beda warna lapisan sebanyak 8 lapisan berdasarkan penampang seperti Gambar 5. 


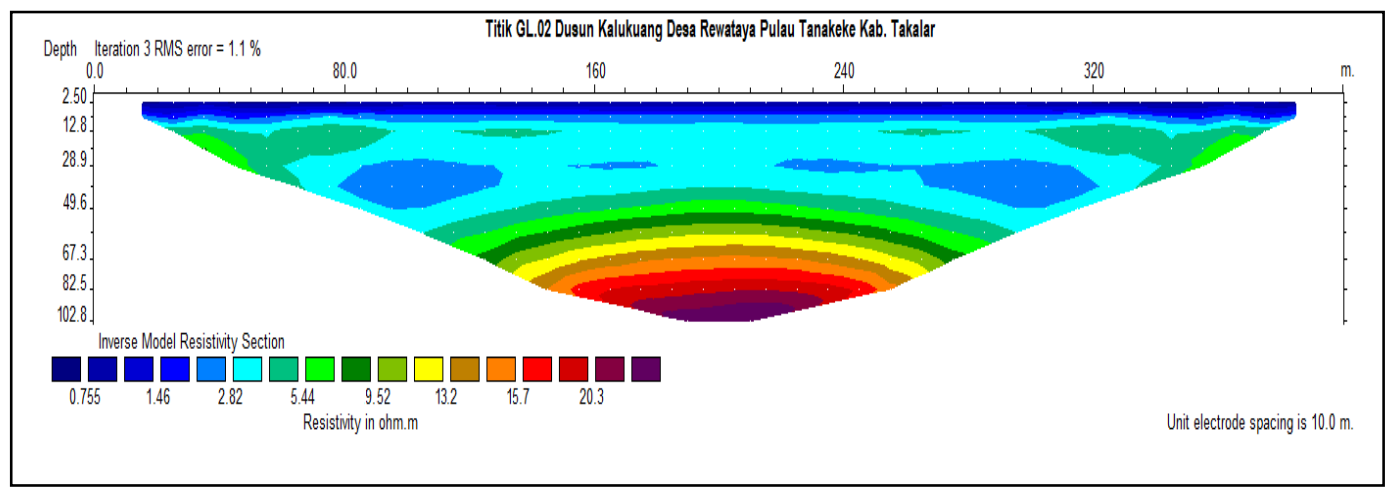

Gambar 5. Penampang Resistivity Geolistrik Lapisan Tanah/Batuan Pengukuran Geolistrik di GL.02 Pulau Tanakeke dengan Interpretasi Kedalaman sekitar 103 Meter.

Susunan lapisan batuan yang terekam dan diinterpretasikan lapisannya sebagai berikut:

a. Lapisan pertama, nilai resistivitas $0,15-1,5 \Omega \mathrm{m}$ dan kedalaman $0-1,5$ meter merupakan lapisan tanah penutup yang berupa alluvial pantai, mengandung air asin.

b. Lapisan kedua, nilai resistivitas 1,5 - $2 \Omega$ m dan kedalaman 1,5 - 8,0 meter merupakan lapisan pasir terumbu yang mengandung air asin dan material berukuran pasir.

c. Lapisan ketiga, nilai resistivitas $2-5,5 \Omega \mathrm{m}$ dan kedalaman 8,0 - 13 meter merupakan lapisan batugamping terumbu yang mengandung material cangkang dan air asin.

d. Lapisan keempat, nilai resistivitas 5,5-8 $\Omega \mathrm{m}$ dan kedalaman 13 - 35 meter merupakan lapisan batugamping berongga yang mengandung air asin.

e. Lapisan kelima, nilai resistivitas $8-11 \Omega \mathrm{m}$ dan kedalaman $35-53$ meter merupakan lapisan batugamping retak yang agak lunak dan mengandung air asin.

f. Lapisan keenam, nilai resistivitas 11-15 $\Omega \mathrm{m}$ dan kedalaman 53 - 65 meter merupakan lapisan batugamping agak keras yang masih mengandung air asin.

g. Lapisan ketujuh, nilai resistivitas 15-20 $\Omega \mathrm{m}$ dan kedalaman 65 - 75 meter merupakan lapisan batugamping keras yang mengandung air asin.

h. Lapisan kedelapan, nilai resistivitas > $20 \Omega \mathrm{m}$ dan kedalaman 75-103 meter merupakan lapisan batugamping yang sangat keras dan masih mengandung air asin.

Dengan melihat kondisi geologi dan interpretasi penampang resisitivity pengukuran geolistrik di Daerah Desa Rewataya ini maka terlihat bahwa secara keseluruhan sampai kedalaman sekitar 103 meter, lapisan tanah dan batuannya mengandung air asin. Lapisan pasir terumbu yang berada pada kedalaman 1,5 Sampai 4,5 hingga 8 meter yang terekam di penampang geolistrik resisitivity menunjukkan lapisan yang mengandung air asin.

\subsection{Model Pengelolaan Air Tanah di Daerah Rapporappowa dan Kalukuang}

Kondisi lapisan tanah dan batuan dari permukaan sampai kedalaman 103 meter yang mengandung air asin di Daerah Rapporappowa dan Kalukuang, Desa Rewataya, Pulau Tanakeke, Kabupaten Takalar ini sehingga model pengelolaan air tanah yang dapat dilakukan di daerah ini hanya bisa dengan Sistem Desalinasi dan penyulingan air laut menjadi air tawar dengan tingkat kejernihan air yang baik sehingga bisa dimanfaatkan secara maksimum oleh warga di Daerah Desa Rewataya, Pulau Tanakeke ini. 
Jurnal Tepat (Teknologi Terapan Untuk Pengabdian Masyarakat), Volume 1, Nomor 1, Tahun 2018

\section{Kesimpulan}

Berdasarkan hasil pengamatan di Daerah Rapporappowa dan Kalukuang, Desa Rewataya, Pulau Tanakeke, Kabupaten Takalar ini, maka dapat disimpulkan:

a. Susunan lapisan tanah dan batuan di daerah ini mulai dari lapisan aluvial pantai, pasir terumbu, batugamping terumbu, batugamping berongga, batugamping retak, batugamping agak keras, batugamping keras dan lapisan batugamping sangat keras.

b. Ketebalan lapisan pasir terumbu $3-6,5$ meter yang berada pada kedalaman antara 1,5 - 4,5 hingga 8 meter dari permukaan tanah di daerah pulau Tanakeke tersebut.

c. Hasil interpretasi nilai resistivity lapisan tanah dan batuan pengukuran geolistrik di Daerah Rapporappowa dan Daerah Kalukuang, Desa Rewataya, Pulau Tanakeke, menunjukkan dari permukaan hingga kedalaman 103 meter mengandung air asin.

d. Model pengeloolaan air tanah di Daerah Pulau Tanakeke ini hanya bisa dengan Sistem Desalinasi dan penyulingan air laut menjadi air tawar dengan tingkat kejernihan air yang baik sehingga bisa dimanfaatkan oleh warga di Daerah Pulau Tanakeke.

\section{Daftar Pustaka}

Adang S.S. dan S.M. Yuningsih. (2009). Determination of Geoelectrical Groundwater Exploration Point in Riang Kemie, East Flores, Jurnal Irigasi, Vol.04 No.1.

Agus Laesanpura dan A. Zainuri. (2009). Metoda Resistivity dan Simulasi dalam Menjelaskan Ketersediaan Air di Pulau Sepekan yang Terisolasi Air Laut, Prosiding PIT IAGI 38

Akos Gyulai, Tamas Ormos, Mihaly Dobroka. (2010). A Quick 2-D Geoelectric Inversion Method Using Series Expansion, Journal of Applied Geophysics, 72.

Arenas DA and Simler L. (1991). Hydrology and Water Resources of Small Islands: A Practical Guide, Studies and Report on Hydrology No. 49 UNESCO.

Cindhy Ade H, Lutfhi A., Ratu Rima B, Riandy S. (2012). Model Aliran Air Tanah, Jurnal Polusi Tanah dan Air Tanah, Departemen Teknik Sipil dan Lingkungan, Universitas Indonesia.

Djoko Tri Y. (2006). Model Manajemen Air Tanah di Cekungan Akuifer Pasuruan untuk Kontinuitas Ketersediaan Terbarukan, Prosiding HATHI XXXIII di Manado.

Dwiyanto, J.S., Sania Indriani, Putranto, T.T. (2009). Studi Potensi Air Tanah di Kota Semarang, Prosiding PIT IAGI XXXVIII, Semarang, ISBN 978-979-8126-21-5.

Eva Rolia. (2011). Penggunaan Metode Geolistrik Untuk Mendeteksi Keberadaan Air Tanah, Jurnal TAPAK Volume 01 Nomor 01, Tahun 2011.

Hantoro W.S., Hadiwisastra S, Masduki A, Susilohadi, Latif H., Kosasih. (2009). Air Tawar di Pulau-Pulau Kecil dan Wilayah Pesisir di Indonesia, Puslit. Geoteknologi, LIPI, Bandung.

Jamal RH dan Sultan. (2012). Analisis Cutting Bor dan Nilai Resistivity Batuan untuk Penentuan Pipa Saringan Sumur Bor Kampus Universitas Hasanuddin, Prosiding Hasil Penelitian Fakultas Teknik, Universitas Hasanuddin.

Kodoatie R.J dan Sjarief, R. (2010). Tata Ruang Air, Penerbit Andi, Yogyakarta.

Muhammad Irfan, Eka J dan Ika Merdeka. (2009). Penentuan Lapisan Akuifer dengan Metode Geolistrik di Lembang, Bandung, Jabar, Prosiding PIT IAGI 38, Semarang.

Noorhadi Rahardjo, Setyawan Purnama, Budi Sulaswono. (2008). Mapping of Springs Potency in Bali Island, Jurnal JRL Volume 4, No. 2 Jakarta, Hal. 71 - 79.

Siti Fatimah dan Sobriyah. (2006). Pelestarian Air Di Pulau - Pulau Kecil, Prosiding HATHI XXXIII di Manado, ISBN 978-979-15616-4-8. 
Sukamto, R dan Supriatna S. (1982). Geologi Lembar Ujungpandang, Benteng dan Sinjai, Sulawesi, P3G, Direktorat Geologi, Departemen Pertambangan RI.

Sultan. (2008). Prospek dan Potensi Air Tanah Dalam Berdasarkan Pengukuran Geolistrik Resistivity Daerah Kab. Tanah Bumbu, Kalimantan Selatan, Jurnal Penelitian Geosains, ISSN 1858 - 3636, Vol.04 No.01, Januari - April 2008, Makassar.

Telford, W.M, Geldart, L.P. and Sheriff, R.E. (1990). Applied Geophysics, Second Edition, Cambridge University Press, United State of America.

Zbigniew Czechowski and Luciano Telesca. (2011). The Construction of an Ito Model for Geoelectrical Signals, Journal Physica A. 